\title{
Class-Based Performance Evaluation: An Evaluation
}

\author{
Fadly Azhar ${ }^{1}$ \\ ${ }^{1}$ Faculty of Education, University of Riau, Pekanbaru, Indonesia \\ Correspondence: Fadly Azhar, Faculty of Education, University of Riau, Pekanbaru, Indonesia. E-mail: \\ drfadly44@gmail.com
}

Received: August 1, 2013 Accepted: August 16, 2013 Online Published: August 30, 2013

doi:10.5539/ass.v9n12p187 URL: http://dx.doi.org/10.5539/ass.v9n12p187

\begin{abstract}
This study aimed to evaluate the implementation of Class-Based Assessment (among teachers Junior High School (SMP) State in Riau Province, Indonesia. The sample consisted of 297 English teachers. This study used the CIPP Evaluation Model which focused on the evaluation of these aspects: input, processes and products. Questionnaires were administered in the collection of data for these factors: input and process; while a checklist was used to collect data for the factor products. Findings for input shows that the training and attitudes towards class-based assessment is at a high level while the aspects of implementation of knowledge and skills in Classroom-Based Assessment is at a moderate level. In the aspect of process, it was found that the frequency aspects of the implementation of the type of class-based assessment is moderate; while aspects of Class-Based Assessment in inviting the experts and aspects of identifying honesty in a large group of students is a major constraint faced by teachers in implementing the Class-Based Assessment. In the aspects of product, it was found that the majority of teachers tend to use the same rubrics as are found in the curriculum. The results showed that there was no significant difference in the level of knowledge, attitudes and skills of teachers to conduct classes based assessment based on their location and school teaching experience. Overall, the sub-aspects of knowledge, attitudes and skills to contribute 41.2 percent of the variable performance-based assessment grades, while 58.8 per cent were attributed to other factors that are not taken into account in this study. Implications of the study is that in order to implement Classroom Based Assessment as a determinant of approval, the proposed school needs to implement a planned and systematic ongoing training, whether working with various parties, inviting experts in the Classroom Based Assessment seminar in school or sending teachers to attend seminars, courses and workshops Classroom-Based Assessment. This study have implications for the existing evaluation system in Indonesian schools because the majority of experts and teachers tend to Class-Based Assessment is seen as a more comprehensive evaluation system.
\end{abstract}

Keywords: classroom-based evaluation, portfolio, input, process, and product

\section{Introduction}

Assessment is a systematic and scientific activity that provides proof of strength and weaknesses (Stufflebeam \& Shinkled, 1985; Rossi et al., 2004; Gredler, 1996). Classroom-Based Assessment is given emphasis in the educational system of Indonesia (Depdiknas, 2002 \& 2003; Yustisia, 2008). Indonesian Minister of Education suggested Classroom-Based Assessment as the core of evaluating learning outcomes (Depdiknas, 2002). Classroom-Based Assessment is seen as a complete evaluation system which includes three main aspects: knowledge, attitudes, and skills. One other strength of class-based assessment is that it involves the seven types of learning outcomes assessment: written, performance, product, project, self / peer, attitude, and overall portfolio which implemented by the teacher in the learning process (on-going assessment). Classroom-Based Assessment focuses on academic exams as well as comprehensively inclusive. Thus, Classroom-Based Assessment is seen as an authentic assessment (O'Mally \& Pierce, 1996).

According to O'Mally and Pierce (1996), authentic assessment refers to assessment process that is based on reflections in teaching, learning, achievement, motivation, and attitude of both teachers and students during teaching-leaning process. In line with this, Darling and Hammond (2000) reiterates that authentic assessment includes four special criteria: (a) a competency, performance, and disposition sample of teachers in the learning process (b) requiring an integration of various aspects of competency and performance; (c) depending on various sources and evidence collected within a period or context; and (d) operating with standard, structure, and professional rubrics. Newmann and Wehlage (1993) also agrees that authentic assessment helps students to 
produce scientific working papers, products, and performance which are very beneficial for them once they graduate. Thus, this study categorizes Classroom-Based Assessment as a form of authentic assessment used as a procedure to evaluate learning outcomes in a classroom.

\subsection{Research Problem}

There is a significant discrepancy in the evaluation process of education in Indonesia when the government policy makers still tend to conduct public examinations in assessing the outcomes of learning and academic achievement (Yustisia, 2008) while the majority of academics and education experts Indonesia considers that the same evaluation system should be reviewed. They suggested that Classroom-based assessment better evaluates students' academic achievement because a school is an agent that has a lot of information about students' set of knowledge, attitudes, and skills (Ahmad, 2007; Syaiful, 2007; Isjoni, 2009; Koto, 2007; Karya, 2009; Nasution, 2007).

Past survey results also show that the skills of teachers in Indonesia were low in preparing and implementing classroom based assessment (Depdiknas, 2003). Kurta and Zmirlib (2008) found that class-based assessment as an alternative assessment is required to assess the student's academic achievement because it will help assess and motivate students towards subjects that they are taking. Studies conducted at the international level also show that the majority of primary school teachers' understanding and implementation of the types of Classroom-Based Assessment especially in the use of the journal, rubric, self / peer assessment, attitude scale, interviews, portfolios, and project assessments is at a low level in their performance (Birgin \& Baki, 2009). This condition occurs because the Class-Based Assessment is a new method of evaluation for teachers in some countries (Birgin $\&$ Baki, 2009).

The findings of earlier studies done by Azhar (2007) found that $40 \%$ of teachers of English secondary schools in Pekanbaru, Indonesia has yet to implement Classroom-Based Assessment directly, 30\% have not completed the concept of class-based assessment as a whole because the questions are provided by the administrative office of education, and another 30\% have difficulty in implementing the Class-Based Assessment for being busy with teaching load, ie, 18-24 hours a week (Azhar, 2007). Preliminary findings have prompted the present study to assess the level of knowledge, attitudes, and skills of teachers of English national high school in Riau Province, Indonesia. The study focused on the implementation of class-based assessment that includes three main aspects: input, process, and product (Stufflebeam et al., 1971).

\subsection{Research Objectives}

This study aims to identify the implementation of Classroom-Based Assessment among junior high school English teacher in Riau, Indonesia. Specifically, this study evaluated three key aspects in the implementation of class-based evaluation of inputs, processes and outputs (products).

In the area of input the study focuses to identify the level of knowledge, attitudes and skills in performing Class-Based Assessment. It also aims to identify differences in knowledge, attitudes and skills in the implementation of class-based assessment based on aspects of school location, academic qualifications, and work experience. Focus is also given to the efforts to identify the effectiveness of the training course related to Class Based Assessment attended by the teachers to be applied in the the educational process at the school.

In aspects of the process, this study aims to identify the process of implementation of Classroom-based Assessment in respect of: (a) aspects of the frequency of implementation of various types of Classroom Based Assessment, (b) aspects of form of support from the principal for teachers and inspectors in the performance of Class-Based Assessment, and (c) aspects of the forms of the constraints faced by teachers in implementing the Class-Based Assessment.

In terms of output or product, the study aims to identify the various types rubric Classroom-Based Assessment and the aspects concerned with the assessment used by teachers to assess and measure student academic achievement, either (a) not implemented directly, (b) perform according to the same rubric by rubric provided in the curriculum, or (c) execute according to different rubric provided in the curriculum.

In addition, this study also investigated the impact, or the contribution of the various sub-aspects of knowledge, attitudes, and skills on all aspects of frequency of implementation for different types of Classroom Based Assessment (evaluation copy, internship, products, projects, self, attitudes, and Portfolio).

\section{Methodology}

This study used the CIPP evaluation model (Stufflebeam et al., 1971). CIPP is a Context, Input, Process, and Product. However, three aspects were investigated, namely input, process, and product. CIPP evaluation model 
has been used in a variety of educational contexts, including evaluation of the implementation of class-based assessment and student academic achievement (Fritz, 1996; Stufflebeam \& Shinkled, 1988; Carpenter, 1998).

Aspects related to the input include demography, knowledge, attitudes, and skills of performing Classroom Based Assessment. While in terms of the process also comprises the frequency of use of the types of Class-Based Assessment, principals and administrative support to the implementation of education Classroom Based Assessment, as well as the constraints faced by teachers in implementation of Classroom Based Assessment. Finally, the product also includes the use of rubric-based assessment by the class teacher to assess and measure the academic achievement of students, determining criteria Mastery learning, and CBA as a report (Stufflebeam \& Shinkled 1985). There are two sets of questionnaires used to collect data from the input factors and process factors. Constructs-constructs and items for factor inputs used in the construction of the questionnaire was adapted and concluded from past studies by Hopkins \& Stanley (1981), Popham (1981), Gronlund (1985), Linn \& Miller (2005), Popham (1995), and Simpson (1966). While constructs and items for the process factor are developed from Oosterhof (2003), Bloom et al (1981), Angelo \& Cross (1993), Brown (2004), Purboyo (2006), and Zakaria (2006). Data collection for the product factor used a checklist based on past studies conducted by Salim \& Ekaningrum (2006), Setiadi (2006), Bastari \& Witjaksono (2006), Tola (2006), and Surapranata (2006). Item selection for this study was done through a filter made through focus group discussions consisting of experts learning psychology at the University of Riau, Indonesia.

Items in the questionnaire is valid and reliable as Cronbach alpha value is exceeded $>0.60$ (Mohd. Majid Konting 1998). The questionnaire contains 5 Pints Likert Scale. Number of samples is randomly selected consisting of 297 random samples of English teacher who taught in junior high schools nationwide.

Data analysis involved descriptive and inferential statistics. Descriptive statistics are used to describe the frequency, percentage, mean score, standard deviation, and the level of Interpretation of the findings. For inferential statistics, this study using the t-test, one-way ANOVA, and multiple regression analysis. Next, to identify the knowledge, attitudes, and skills of teachers to conduct classes based assessment, also includes the benefits of the various concepts of the Class Based Assessment exercised in a variety of training, the interpretation is as follows: 1:00 to 2:33 (low); 2:34 - 3.66 (medium), and 3.67 - 5.00 (high) (Santoso, 2006; Pallant, 2007; Baba, 1992).

\section{Results and Discussions}

In input aspect that is showing the teachers attended the training, the results showed that the mean score was at a high level. The mean score of teachers' knowledge-based assessment was moderate Class (3:29 to 3:55). The mean score for attitude towards class-based assessment was high $(3.77-3.95)$, but the skills of teachers to conduct classes based assessment was moderate (3:27 to 3:56). This means that even if teachers have a high attitude towards class-based assessment, they have the knowledge and skills that simple. This suggests that the competence of teachers in Classes Based Assessments still needs a lot of training. Thus, meaningful and continuing training should either be implemented by the school (the school) or various external parties. Tienken and Michael (2001) explained that teachers need ongoing training to enhance the learning and performance of Class-Based Assessment. Sumaryanto (2005) also agreed that continuous training of Class-Based Assessment is required because his study found that $80 \%$ of primary school teachers in the city of Semarang, Central Java Indonesia did not understand the Classroom Based Assessment. This point is supported by McMilan (2000) who states that teachers and education ministry must implement a variety of training for success. Gimin (2002) who found that skills and training contribute significantly to the performance and competence of teachers, also supported training for teachers on an ongoing basis. Petkovskaa et al. (2010) suggest that training with respect to the types of classroom-based assessment is required of the teacher. His research in the Republic of Macedonia found that the implementation of training classes based assessment is an important tool for the evaluation and measurement of student academic achievement in the successful implementation of assessment in the country.

About aspects of the process, the mean score in terms of frequency of use of seven classes based assessment is moderate $(2.76-3.63)$. The lowest mean score was in project assessment and the highest mean score on self / peer assessment. This matter is caused by several factors: low creativity, curiosity, limited sources, inactive teacher association, over teaching load, limited Chances to attend seminars, conferences, and workshops. In the context of self / peer assessment, Noonan and Randy (2005) found that this assessment is very useful for assessing academic achievement. Malabonga et al. (2005) noted that $92 \%$ of students have a good competence in using the rubric self / peer through the computer. Ross (2006) Ross (2006) also explained that the strength of the self / peer assessment is dependent on the way to train their students to evaluate their own work either with or without the help of teachers. 
However, students who have a negative attitude in peer assessment (Cheng \& Martin, 2005). With respect to portfolio assessment, Forgette and Marielle (2000) explains that there is a significant correlation between the input variables and the process of implementation of various portfolio assessment issue if both were jenerik frame completed properly. Therefore, Leahy (2005) explains that the portfolio as a daily assessment used to assist the process of evaluation. Meanwhile, Munoto andMeini Sondang (2006) says that the portfolio rubric is necessary to involve students in the context of exploration, discussion, tests, and whether the concept of learning in groups or individually. Garman and Prantanida (1991), Tierney (1991), and Ali (2005) concluded that students' academic achievement through portfolios will reflect the actual item so that they can be used to show to anyone, including parents. In the context of performance assessment, Quellmatz et al. (1999) suggest that the evaluation system should be focused on the central performance by students. Parallel to this, Brualdi (1998) explains that the performance assessment is indispensable as an endorsement of anything that is recovered by the students through their memory. However, Liang and Creasy (2004) argue that an assessment of the progress of learning, especially in performance, played by student assessment is to be reviewed through Web-CT which analyzes perception and experience of the trainers. In the context of attitude assessment, Olson and Zanna (1993) found that IQ factors, temperament, sentiments, clans, and beliefs influence one's attitude. For this, Anastasi (1992) and Fraenkel (1980) explained that one purpose of the assessment is to identify students' attitudes towards the various components involved in the subject, the teacher, the learning process, the explanation in the text book, and so on.

To support aspects of the implementation of Classroom-Based Assessment, it is found that inviting experts of Classroom Based Assessment is not supported by the principals and inspectors. While the aspect constraints faced by teachers in the implementation of Classroom-Based Assessment found that nearly all teachers find it difficult to identify honesty in students. However, the aspects of the product found that the majority of teachers tend to use the same rubric found in the curriculum. This matter is due to low confidence in using the project rubric, self / peer, attitude, and portfolio assessments. Past studies found that class-based assessment as authentic assessment, formative, summative, internal assessments with respect to the learning process will help students produce scientific writing, products, and performance that is very useful for them when they graduate (Ariev, 2005; Sapaat, 2004; Muchtar, 2010; Boston, 2002; Mistilina, 2006; Zunairi, 2008).

Findings indicated that there were no significant differences in knowledge, attitudes, and skills for Classroom-Based Assessment based on their location and school teaching experience. While the academic aspect that teachers who have obtained a bachelor's level of knowledge, attitudes, and skills that are better than the teacher s who have diploma. Overall, the sub-aspects of knowledge, attitudes, and skills to contribute, impact, and contribution of $41.2 \%$, while $58.8 \%$ was contributed by other factors are not accounted for in this study.

Generally, if the teacher wishes to assess and measure student academic assessment in the context of doing an activity, then the performance assessment used; while in the context of research, project assessment used. Hafner and Hafner (2003) concluded that the rubric is valid and reliable for assessing and measuring the progress of learners because rubric is an effective strategy in the learning process including learning science. Andrade and Ying (2005) also agreed that the use of rubric will help students focus on their work, produce quality work, as well as scores better value. Moskal and Jon (2000) noted that the rubric is required in Classroom Based Assessment to ti-all rubric must meet the level of validity and reliability.Tierney and Marielle (2004) explains that many of the rubrics do not work very well in the learning process due to the lack of consistency and are not suitable for the assessment of student academic achievement. Muhammad Yaumi (2005) stated that the teacher become busier as they have a role not only as facilitators but also as supervisors in the implementation of class-based assessment. Therefore, teachers must have knowledge and ability to plan for the learning process, students' agenda, Quizzes, Modules, and Classroom Based Assessment rubric. Tillema et al. (2011) explain that the class-based assessment used should be of a good quality. Therefore, Classroom Based Assessment process must be focused on construction and implementation process and involving students in evaluation and measurement activities.

\section{Implications and Recommendations}

This study has implications for the process of evaluation in education, especially in Indonesia. As the teachers in the study had a positive attitude towards the implementation of school-based assessment, a more holistic effort primarily involving the top is running the evaluation. Even so, this study found that teachers still have shallow knowledge in school-based assessment and less skilled in the implementation, and therefore a comprehensive training framework is needed. The school and the education ministry are advised to use the training model designed by Pont (1991). This model starts with needs analysis, design approach, development of training materials, conducting training, and ends with evaluations conducted for each activity. 
In addition, for teachers skills development, it is recommended to use the types of Classroom-Based Assessment (except written assessments) due the consideration of the use of the Internet. Recognizing that there are teachers who do not have Internet access, direct methods can be carried out. In a portfolio context, it is proposed that they limit the involvement of teachers in the course of filing. Teachers need to be trained in a practical portfolio management, including the use of electronic portfolio which are accessible via the Internet. To enhance teachers' motivation to use project evaluation rubric, self / peer, attitude, and portfolios, it is recommended that teachers train themselves constantly. The effect is that teachers will become accustomed to using assessments as Classroom Based Assessment. Other recommendations are that teachers must work closely with experts in the use of assessments through seminars and workshops among teachers association or assembly.

\section{References}

Ahmad, D. (2007). Why are there only three subjects when there is a good system? (Sistem sudah bagus, kenapa hanya tiga mata pelajaran?) Pekanbaru: Riau Pos.

Ali, Y. S. (2005). An introduction to electronic portfolios in the language classroom. The Internet TESL Journal, XI(8). Retrieved August 18, 2011, from http://iteslj.org

Anastasi, A. (1992).Psychological testing (5th ed.). New York: MacMillan Publishing Co.

Andrade, H., \& Ying, D. (2005). Student perspectives on rubric-referenced assessment. PAREonline.net, 10(3). Retrieved May 17, 2007, from http://PAREonline.net

Angelo, A. T., \& Cross, P. K. (1993). Classroom assessment techniques: A handbook for college teachers (2nd ed.). San Fransisco: Jossey-Bass Publishers.

Ariev, R. P. (2005). A theoretical model for the authentic assessment of teaching. PAREonline.net, 10(2). Retrieved June 28, 2007 from, http://PAREonline.net

Azhar, F. (2007). Teacher's perception in implementation of Classroom based assessment in Teaching and Learning (Persepsi guru tentang pelaksanaan Penilaian Berasaskan Kelas dalam P\&P): Satu kajian awal. Pekanbaru: Penerbitan Fkip-Unri.

Baba, A. (1992). A study on the relationship between achievement in science and background on cognitive style, logical thinking skills and science skills process among secondary school students. (Kajian pertalian antara pencapaian sains dan latar belakang dengan gaya kognitif, kemahiran berfikir secara logik dan kemahiran proses sains di kalangan pelajar sekolah menengah.) Thesis by Dr. Fal. Universiti Kebangsaan Malaysia, Bangi.

Bastari, \& Witjaksono. (2006). Assessment Project: Guidance Module for Classroom based assessment (Projek penilaian: Modul pedoman penilaian di kelas). Jakarta: Centre for Educational Assessment Research and Development Agency, Ministry of National Education. (Pusat Penilaian Pendidikan Badan Penelitian dan Pengembangan, Departemen Pendidikan Nasional).

Birgin, O., \& Baki, A. (2009). An investigation of primary school teachers' proficiency perceptions about measurement and assessment methods: the case of Turkey. Procedia Social and Behavioral Sciences, 1, 681-685. Retrieved August 4, 2011, from http://www.sciencedirect.com http://dx.doi.org/10.1016/j.sbspro.2009.01.119

Bloom et al. (1971). Handbook on formative and summative evaluation of students learning. New York: McGraw-Hill Inc.

Bloom et al. (1981). Evaluation to improve learning. New York: McGraw-Hill Inc.

Bloom, B. S., Krathwohl, R. D., \& Maisa. (1973). Taxonomy of educational objectives: The classification of educational goals (Handbook ii: Affective domain). London: Longman Inc.

Borg, W. L., \& Gall, M. D. (1983). Educational research: An introduction. New York: Longman Inc.

Boston, C. (2002). The concept of formative assessment. Retrieved May 20, 2007, from http://PAREonline.net

Brown, H. D. (2004). Language assessment: Principles and classroom practices. New York: Pearson Education Inc.

Brualdi, A. (1998). Implementing performance assessment $n$ the classroom. Retrieved May 20, 2007, from http://PAREonline.net

Cheng, W., \& Martin, W. (2005). Peer aassessment of language proficiency. Department of English. The Hong Kong Polytechnic University, Hung Hom, Kowloon, Hong Kong. 
Darling, L., \& Hammond, L. (2000). Authentic assessment of teaching in context. Teaching and Teacher Education, 16, 523-545. http://dx.doi.org/10.1016/S0742-051X(00)00015-9

Depdiknas. (2002). Competence-based curriculum. Central Jakarta: Curriculum Center. (Kurikulum berbasis kompetensi. Jakarta Pusat: Pusat Kurikulum). Balitbang, Department of National Education (Departemen Pendidikan Nasional).

Depdiknas. (2002). Decision of the Minister of National Education Republic of Indonesia (Keputusan Menteri Pendidikan Nasional Republik Indonesia) No. 047/U/2002 on 4 April 2002 Chapter III verse 3 about Classroom based assessment (tentang Penilaian Berasaskan Kelas). Jakarta: Department of National Education (Departemen Pendidikan Nasional).

Depdiknas. (2003a). Results of need assessment guru SMP. Jakarta Directorate of Extended Education Department of National Education: Direktorat Pendidikan Lanjutan Pertama, (Departemen Pendidikan Nasional).

Depdiknas. (2003b). Competence-based curriculum in Secondary School.Central Jakarta: Curriculum Center. (Kurikulum Berbasis Kompetensi Sekolah Menengah Pertama (SMP)): Specific guidelines on expansion of Competence-based Assessment System in Secondary School (Pedoman Khusus Pengembangan Sistem Penilaian Berbasis Kemampun Dasar Sekolah Menengah Pertama). Jakarta: Directorate of Extended Education. Directorate General of Elementary and Secondary Education, Ministry of National Education. (Direktorat Pendidikan Lanjutan Pertama. Direktorat Jenderal pendidikan Dasar dan Menengah, Departemen Pendidikan Nasional).

Forgette, G. R., \& Marielle, S. (2000). Organizational Issues Related to Portfolio Assessment Implementation in the Classroom. Retrieved June 21, 2007, from http://PAREonline.net

Fraenkel, J. R. (1980). Helping students think and value: Strategies for teaching the social studies (2nd ed.). New Jersey: Prentice-Hall Inc.

Fritz, S. (1996). Assessing undergraduate student needs utilizing the CIPP model of evaluation. Disertasi Ph.D. University of Idaho.

Garman, N., \& Prantanida, M. (1991). The academic professional portfolio. The Australian Administrator. A Professional Publication for Educational Administrators, School of Education, Deakin University.

Gimin. (2002). Analysis of the influence of the training and mentoring for small entrepreneurs to business success. Case studies on small industries in the Yogyakarta province (Analisis pengaruh pelaksanaan pelatihan dan pendampingan pengusaha kecil terhadap keberhasilan usaha. Studi kasus pada industri kecil kulit di propinsi daerah istimewa Yogyakarta). Doctoral Dissertation (Disertasi Doktor). Malang University (Universitas Negeri Malang). Postgraduate Programme in Economics (Program Pasca Sarjana PSSJ Pendidikan Ekonomi).

Gredler, M. E. (1996). Program evaluation. New Jersey: Merrill-Prentice HallInc.

Gronlund, E. N. (1985). Stating objectives for classroom instruction. New York: The Macmillan Publishing Co.

Gurning, B. (2007). UN for educational standard (UN untuk standard pendidikan).Pekanbaru: Riau Pos.

Hafner, J., \& Hafner, P. (2003). Quantitative analysis of the rubric as an assessment tool: An empirical study of student peer-group rating. International Journal of Science Education, 25(12), 1509-1528. http://dx.doi.org/10.1080/0950069022000038268

Hopkins, D. K., \& Stanley, C. J. (1981). Educational and psychological measurement and evaluation. New Jersey: Prentice-Hall Inc.

Isjoni. (2009). Controversials of National Testing (Kontroversi ujian nasional). Pekanbaru: Riau Pos.

Karya, D. (2009). National examinations needs improvement: The standard of education is different (Ujian nasional perlu pembenahan: Standar pendidikan masih beda). Pekanbaru: Riau Pos.

Koto, A. (2007). Riau rejects National Tests (Riau tolak Ujian Nasional). Pekanbaru: Tribun Pekanbaru.

Krueger, R. A. (1994). Focus groups: A practical guide for applied research. Newbury Park, CA: Sage Publication.

Kurta, A., \& Zmirlib, S. (2008). The views of teacher candidates about the use of a scoring rubric for the evaluation of their products in the course of instructional technologies and material development. Procedia social and Behavioral Sciences, 1, 988-992. Retrieved June 22, 2010, from http://www.sciencedirect.com 
Leahy et al. (2005). Classroom assessment minute by minute, day by day. Educational Leadership, 63(3). Retrieved June 26, 2007, from http://search.ebscohost

Liang, X., \& Creasy, K. (2004). Classroom assessment in web-based instructional environment: Instructors' experience. University of Akron \& Slippery Roc University. Retrieved June 25, 2007, from http://PAREonline.net

Linn, L. R., \& Miller, M. D. (2005). Measurement and assessment in teaching. New Jersey: Pearson Education Inc.

Mcmillan, J. H. (2000). Fundamental principles for teachers and school administrators. Virginia Commonwealth University. Retrieved June 28, 2007, from http://PAREonline.net

Mistilina, S. (2006). Supporting change in classroom assessment. Educational Leadership, 64(4), 76-79.

Moskal, M. B., \& Jon, L. A. (2000). Scoring rubrics development: Validity and reliability. Retrieved July 1, 2007, from http://PAREonline.net

Muchtar, H. (2010, June). Application of authentic assessment in the efforts to improve the quality of education (Penerapan Penilaian autentik dalam upaya peningkatan mutu pendidikan). Jurnal Pendidikan Penabur, 14(9).

Munoto, \& Sondang, M. (2006). Development of portfolio assessment tools to improve students' achievement motivation in Electric Circuits I course in the Department of Electrical Engineering UNESA (Pengembangan perangkat penilaian portfolio untuk meningkatkan motivasi berprestasi mahasiswa pada mata kuliah Rangkaian Listrik I di Jurusan Teknik Elektro UNESA). Electrical Engineering Education Program, Department of Electrical Engineering, Faculty of Engineering, State University of Surabaya (Program Studi Pendidikan Teknik Elektro, Jurusan Elektro, Fakultas Teknik, Universitas Negeri Surabaya).

Nasution, N. (2007). Making it more difficult: UN subjects added (Makin memberatkan: Mata pelajaran UN ditambah). Pekanbaru: Riau Pos.

Newmann, F. M., \& Wehlage, G. G. (1993). Five standards of authentic instruction. Educational Leadership, $50(7), 8-12$.

Noonan, B., \& Randy, D. C. (2005). Peer and self-assessment in high schools. University of Saskatchewan

O’Maley, J. M., \& Pierce, L. V. (1996). Authentic assessment for English language learner. Boston: Addison-Wesley Publishing Co.

Olson, J. M., \& Zanna, M. P. (1993). Attitude and attitude change. Annual Review of Psychology, 44, 117-154. http://dx.doi.org/10.1146/annurev.ps.44.020193.001001

Oosterhof, A. (2003). Developing and using classroom assessments. New Jersey: Pearson Education Inc.

Pallant, J. (2007). SPSS survival: A step-by step guide to data analyis using SPSS for Window (10th ed.). New South Wales, Australia: Allen \& Unwin.

Petkovskaa et al. (2010). Primary school education standards for student's assessment in primary school. Procedia Social and Behavioral Sciences, 2, 2366-2370. Retrieved May 18, 2011, from http://www.sciencedirect.com

Pont, A. M. (1991). Developing effective training skills. London: McGrow-Hill Book Co.

Popham, W. J. (1981). Modern educational measurement. New Jersey: Prentice-Hall Inc.

Popham, W. J. (1995). Classroom assessment: What teachers need to Know. Boston: Pearson Education Inc.

Purboyo, B. R. (2006). Classroom based assessment (Penilaian berbasis kelas). Jakarta: Research and Assessment Dept. Post Graduate Program State University of Jakarta.

Ross, A. J. (2006). The reliability, validity, and utility of self-assessment. PAREonline.net, 11(10). Retrieved July 3, 2007, from http://PAREonline.net

Rossi, H. P., Lipsey, W. M., \& Freeman, E. H. (2004). Evaluation. A systematic approach (7 ed.). London: Sage Publications.

Santoso, S. (2006). Mastering statistics in the information age with SPSS. (Menguasai statistik di era informasi dengan SPSS). Jakarta: PT. Elex Media Komputindo. 
Sapaat. (2004). Use authentic assessment: Replacement approach to UAN (Gunakan asesmen autentik: Pendekatan pengganti UAN). Retrieved April 14, 2007, from http://www.pikiranrakyat.com

Setiadi, H. (2006). Assessment work: Module assessment guidelines in the classroom. Jakarta: Educational Assessment Research and Development, Ministry of National Education (Penilaian kerja: Modul. Pedoman penilaian di kelas. Jakarta: Pusat Penilaian Pendidikan Badan Penelitian dan Pengembangan, Departemen Pendidikan Nasional.)

Simpson, E. J. (1966). The classification of educational objectives: Psychomotor domain. Illinois: Illinois Teacher of Home Economics.

Stufflebeam et al. (1971). Educational evaluation and decision making. Hance, IL: Peacock.

Stufflebeam, D. L. (1971). The relevance of CIPP evaluation model for educational accountability. Journal of Research and Development in Education Fall, 19-25.

Stufflebeam, D. L., \& Shinkled, A. J. (1985). Systematic evaluation: A self guide to theory and practice. Boston: Kluwer-Nijhoff Publishing.

Stufflebeam, D. L., \& Shinkled, A. J. (1988). Systematic evaluation. Norwell: Kluwer-Nijhof Publishing.

Surapranata, S. (2006). Guidelines for the development of portfolio assessment: Module assessment guidelines in the classroom. Jakarta: Educational Assessment Research and Development, Ministry of National Education. (Pedoman pengembangan penilaian portfolio: Modul pedoman penilaian di kelas. Jakarta: Pusat Penilaian Pendidikan Badan Penelitian dan Pengembangan, Departemen Pendidikan Nasional.)

Syaiful, P. (2007). The Crisp Education Minister (Mendiknas yang garing). Pekanbaru: Riau Pos.

Tierney, R. J. (1991). Portfolio assessment in the reading and writing classroom. California: Christopher-Gordon Publisher Co.

Tierney, R., \& Marielle, S. (2004). What's wrong with rubrics: focusing on the consistency of performance criteria across scale levels. Retrieved July 6, 2007, from http://PAREoline.net

Tillema et al. (2011). Assessing assessment quality: Criteria for quality assurance in design of (peer) assessment for learning: A review of research studies. Studies in Educational Evaluation, 37, 25-34.

Tola, B. (2006). Self-assessment: Module assessment guidelines in the classroom. Jakarta: Educational Assessment Research and Development, Ministry of National Education (Penilaian diri: Modul pedoman penilaian di kelas. Jakarta: Pusat Penilaian Pendidikan Badan Penelitian dan Pengembangan, Departemen Pendidikan Nasional.)

Yaumi, M. (2005). KBK: Between wishes and reality (Antara harapan dan kenyataan). Retrieved July 17, 2008, from http://www.uni.edu/yaumi

Yustisia, T. P. (2008). Complete guide to curriculum level education units (Panduan lengkap kurikulum tingkat satuan pendidikan). Yogyakarta: Pustaka Yustisia.

Zakaria, R. T. (2006). Attitude assessment guidelines: Module assessment guidelines in the classroom. Jakarta: Educational Assessment Research and Development, Ministry of National Education (pedoman penilaian sikap: Modul pedoman penilaian di kelas. Jakarta: Pusat Penilaian Pendidikan Badan Penelitian dan Pengembangan, Departemen Pendidikan Nasional.)

Zunairi. (2008). Internal assessment as classroom assessment model (Internal assessment sebagai model penilaian kelas). Jurnal Paradigma, XIII(25).

\section{Copyrights}

Copyright for this article is retained by the author(s), with first publication rights granted to the journal.

This is an open-access article distributed under the terms and conditions of the Creative Commons Attribution license (http://creativecommons.org/licenses/by/3.0/). 